\title{
Standardization of Planting Geometry of Sugarcane with Suitable Intercropping under Drip Irrigation in Chhattisgarh Plains
}

\author{
C.K. Chandrakar ${ }^{1}$, N. Prabha ${ }^{1}$, O.N. Verma ${ }^{1}$ and K.K. Pandey ${ }^{2 *}$
}

I'Agronomy), S. K. College of Agri. and Res. Station, Kawardha, IGKV, Raipur, India

${ }^{2}$ Agril. Statistics, DKS College of Agri. and Res. Station, Bhatapara, IGKV, Raipur, India

*Corresponding author

\section{A B S T R A C T}

Keywords

Chemical attributes,

Inter cropping,

Planting geometry and yield attributes

\section{Article Info}

Accepted:

26 June 2019

Available Online:

10 July 2019
The present study carried out the importance of drip irrigation in sugarcane and vegetable cultivation in intercrop (onion) under the Randomized Block Design with 8 treatment and three replications. Under the study the Plot size $6 \mathrm{~m} \times 5 \mathrm{~m}$ and fertilizer doses as 250:100:150 kg NPK/ha for the sugarcane variety Co-86032. Treatment No. 6 (T6- $150 \mathrm{~cm} * 120 \mathrm{~cm})$ found best for number of tillers, Plant height $(\mathrm{cm})$ and Nodal length $(\mathrm{cm})$ 19.33, $3.88 \mathrm{~cm}$ and $15.00 \mathrm{~cm}$ respectively. Treatment $1(\mathrm{~T} 1-120 \mathrm{~cm} * 60 \mathrm{~cm})$ found best for Girth $(\mathrm{cm})$ i.e. $9.17 \mathrm{~cm}$. Best yield found in Treatment 1 (160.67 t/ha) and maximum Juice \% in T-6 69.63\%.

\section{Introduction}

Sugarcane (Saccharum officinarum) is an important commercial crop as 78 per cent of world sugar is produced from sugarcane. India ranks second, after Brazil, in area and production of sugarcane. The area occupying in the country is 4.7 million ha with the production of 28.10 million tons respectively (Anon, 2016).

Planting geometry is important agronomic factor to determine sugarcane yield. Farmers of Chhattisgarh plain region do not prefer to go beyond $90 \mathrm{~cm}$ row to row distance which causes less tillering and less robust plant growth. Wider spacing helps in easy penetration of sunlight and air which helps in healthy growth of seedlings and controls pests and pathogens to some extent. Wider spacing helps to take intercropping and mechanical weeding in-between beds can be used to raise multiple intercrops, generating supplemental income. There are scientific studies conducted in research stations, which state that wide row spacing leads to higher yield and net returns and reduced cost of cultivation (Rajula Shanthy and Muthusamy, 2012). 
Farmers of this region adopt two and three eye budded sets for commercial cultivation, a huge quantity of cane stalk cuttings of 6-8 t/ha having 3-bud pieces is required. One of the major expenditure in sugarcane production is the seed cane, the planting material which is required in huge quantity. Now-a-days the method bud chip technology in sugar cane has become popular in comparison to the traditional method of planting, where two or three bud sets are used. Using bud chip settlings with application of improved production technology for nursery management, settling transplanting methods and time, plant spacing, weed control, nutrient requirement, irrigation scheduling and optimum time of cane harvesting, good cane yield can be achieved. Farmers can increase their income as well as increase sugarcane yield using bud chip settlings with good management practices

High value and remunerative crops like vegetables, potato, onion, oilseeds and pulses offer great scope for growing as intercrops and in further providing additional income and reducing risks in the long duration crop of sugarcane as well as in improving land use efficiency. Keeping all these aspects in view, the present investigation was carried out Standardization of planting geometry of sugarcane with onion intercropping under drip irrigation in Chhattisgarh plain.

\section{Materials and Methods}

The field experiment was conducted at Sant Kabir College of Agriculture and Research Station, Kawardha, Dist.-Kabirdham (Chhattisgarh) under Chhattisgarh plain zone. During 2016-17 on Rabi season on month of November, The total rainfall $750 \mathrm{~mm}$ occurred during the entire 12 months crop growth period. The soil of experimental site was medium deep black. The details of experiment with regard to crop, variety, and the treatments evaluated, the design adopted and plot size are provided in table 5. Initially the land was ploughed once with tractor drawn mouldboard plough and later on worked twice with the cultivator. The land was then harrowed and smoothened to bring the seed bed to a fine tilth. The field was then laid out as described below under different row spacings. Sugarcane nursery generated by polybag techniques which are transplanted after 30 days on main field. Irrigation is made by drip system

On the day of planting, full doses of phosphorus, potash along with 10 per cent of the recommended nitrogen were applied in the form of diammonium phosphate (DAP), muriate of potash (MOP) and urea respectively through fertigation. The rest of the nitrogen is top dressed by urea fertilizer through fertigation in different interval.

Respectively. The recommended dose of fertilizers were applied to the intercrops viz. Onion, at 50 per cent of the total nitrogen and full doses of phosphorus and potash were applied at sowing in furrows by mixing with the soil and remaining 50 per cent nitrogen was top dressed at 30 days after sowing (DAS). From nine months old sugarcane crop (cv. Co86032) raised for seed multiplication. One eye buds are detached from cane through bud chipper. The nursery of onion intercrops onion were also tranplanted between two sugarcane rows on $20 \mathrm{~cm}$ row spacing. The plots were irrigated three days in a week by drip method. During each time of irrigation, the water was supplied four hours per day. The rate of discharge of water in drip lines was two liters per hour.

\section{Results and Discussion}

\section{Influence of different wider row spacings on growth and yield of cane}

Cane yield is a function of yield attributing characters such as number of millable canes 
(NMC), single cane weight, internodal length and cane diameter at harvest. In the present investigation, the data revealed that, number of millable canes (19.33), plant height (3.88 $\mathrm{cm})$, nodal length $(15.00 \mathrm{~cm})$ was significantly maximum under T6 $150 \mathrm{~cm} \times 120 \mathrm{~cm}$ while girth of sugarcane was maximum $(9.17 \mathrm{~cm})$ under $(\mathrm{T} 1-120 \mathrm{~cm} \times 60 \mathrm{~cm})$. Whereas single cane weight and cane yield was significantly higher $160.67 \mathrm{t} / \mathrm{ha}$ under T1- $120 \mathrm{~cm} \times 60 \mathrm{~cm}$ compared to Farmer practices and other treatments (Table 1). This could be attributed to more efficient utilization of moisture, nutrients and solar energy with less inter and intra plant competition in sugarcane grown at $120 \mathrm{~cm} \times 60 \mathrm{~cm}$ spacing. The results are in agreement with Patel et al., (2014b). The marked increase in yield at $120 \mathrm{~cm}$ spacing appears due to better light interception, greater availability of moisture, more aeration to individual setts and increased plant population; better tillering and tiller retention which resulted in taller stalks and increased cane weight at harvest compared to the rest of plant geometries (Patel et al., 2014b).

In case of onion intercropping, sugarcane equivalent yield was also significantly higher (190.30 q /ha) under spacing of T1- $120 \mathrm{~cm} \times$ $60 \mathrm{~cm}$ (Table 2). Onion exerted least detrimental effect on the emergence, tiller, millable cane and yield of sugarcane (Hossain, 1984). The results are also in conformity with Saini et al., (2003) (Fig. 1 and 2).

Table.1 Effect of planting geometry to growth parameters of sugarcane crop under drip irrigation at Kawardha region

\begin{tabular}{|c|c|c|c|c|}
\hline Treatments & $\begin{array}{l}\text { Number of } \\
\text { tillers }\end{array}$ & $\begin{array}{l}\text { Plant height } \\
\text { (cm) }\end{array}$ & $\begin{array}{l}\text { Nodal length } \\
\text { (cm) }\end{array}$ & Girth $(\mathbf{c m})$ \\
\hline$T 1-120 \mathrm{~cm} * 60 \mathrm{~cm}$ & 16.33 & 3.60 & 14.53 & 9.17 \\
\hline$T 2-120 \mathrm{~cm} * 90 \mathrm{~cm}$ & 16.50 & 3.75 & 14.77 & 8.40 \\
\hline T3- $120 \mathrm{~cm} * 120 \mathrm{~cm}$ & 18.50 & 3.81 & 14.90 & 8.54 \\
\hline T4- $150 \mathrm{~cm} * 60 \mathrm{~cm}$ & 18.00 & 3.61 & 14.42 & 8.87 \\
\hline$T 5-150 \mathrm{~cm} * 90 \mathrm{~cm}$ & 18.67 & 3.59 & 14.80 & 8.56 \\
\hline T6- $150 \mathrm{~cm} * 120 \mathrm{~cm}$ & 19.33 & 3.88 & 15.00 & 8.40 \\
\hline $\begin{array}{l}\text { T7- FP with } 2 \text { eye } \\
\text { bud }\end{array}$ & 8.67 & 2.95 & 13.20 & 7.23 \\
\hline $\begin{array}{l}\text { T8- FP with } 3 \text { eye } \\
\text { bud }\end{array}$ & 6.50 & 2.77 & 12.73 & 7.33 \\
\hline $\operatorname{SeM} \pm$ & 1.02 & 0.18 & 0.47 & 0.54 \\
\hline CD at $5 \%$ & 2.06 & 0.37 & 0.95 & 1.0 \\
\hline
\end{tabular}


Table.2 Effect of planting geometry to sugarcane yield attributes under drip irrigation at Kawardha region

\begin{tabular}{|c|c|c|c|c|}
\hline Treatments & $\begin{array}{c}\text { Sugarcane yield } \\
\text { (t/ha) }\end{array}$ & $\begin{array}{l}\text { Single cane } \\
\text { weight }(\mathbf{k g})\end{array}$ & $\begin{array}{l}\text { Intercrop } \\
\text { (onion) yield } \\
\text { (q/hq) }\end{array}$ & $\begin{array}{l}\text { Sugarcane } \\
\text { equivalent } \\
\text { yield (q/ha) }\end{array}$ \\
\hline$T 1-120 \mathrm{~cm} * 60 \mathrm{~cm}$ & 160.67 & 1.86 & 88.89 & 190.30 \\
\hline$T 2-120 \mathrm{~cm} * 90 \mathrm{~cm}$ & 140.33 & 1.82 & 85.56 & 168.85 \\
\hline$T 3-120 \mathrm{~cm} * 120 \mathrm{~cm}$ & 129.67 & 1.77 & 87.78 & 158.93 \\
\hline$T 4-150 \mathrm{~cm} * 60 \mathrm{~cm}$ & 152.51 & 1.90 & 100.00 & 185.84 \\
\hline$T 5-150 \mathrm{~cm} * 90 \mathrm{~cm}$ & 123.67 & 1.73 & 102.22 & 157.74 \\
\hline T6- $150 \mathrm{~cm} * 120 \mathrm{~cm}$ & 117.83 & 1.68 & 104.44 & 152.65 \\
\hline T7- FP with 2 eye bud & 112.47 & 1.19 & 70.56 & 135.99 \\
\hline T8- FP with 3 eye bud & 109.63 & 1.30 & 69.78 & 132.89 \\
\hline $\mathrm{SeM} \pm$ & 7.57 & 0.18 & 5.21 & 7.22 \\
\hline CD at $5 \%$ & 15.30 & 0.37 & 10.54 & 14.59 \\
\hline
\end{tabular}

Table.3 Effect of planting geometry to chemical attributes of sugarcane under drip irrigation

\begin{tabular}{|c|c|c|c|c|c|}
\hline Treatments & Brix \% & Purity \% & Juice \% & Sucrose \% & Recovery \% \\
\hline$T 1-120 \mathrm{~cm} * 60 \mathrm{~cm}$ & 20.46 & 83.60 & 67.48 & 13.56 & 12.17 \\
\hline$T 2-120 \mathrm{~cm} * 90 \mathrm{~cm}$ & 20.41 & 82.93 & 67.53 & 13.98 & 12.19 \\
\hline T3- $120 \mathrm{~cm} * 120 \mathrm{~cm}$ & 20.94 & 83.54 & 68.47 & 13.86 & 12.93 \\
\hline T4- $150 \mathrm{~cm} * 60 \mathrm{~cm}$ & 20.93 & 83.28 & 67.67 & 13.62 & 12.02 \\
\hline T5 $-150 \mathrm{~cm} * 90 \mathrm{~cm}$ & 20.60 & 83.81 & 67.78 & 13.88 & 12.11 \\
\hline T6- $150 \mathrm{~cm} * 120 \mathrm{~cm}$ & 20.70 & 83.66 & 69.63 & 13.79 & 12.51 \\
\hline T7- FP with 2 eye bud & 19.97 & 82.43 & 63.64 & 11.64 & 11.07 \\
\hline T8- FP with 3 eye bud & 19.48 & 81.74 & 63.43 & 11.03 & 11.10 \\
\hline $\mathrm{SeM} \pm$ & 0.73 & 1.19 & 2.17 & 0.49 & 0.45 \\
\hline CD at $5 \%$ & NS (1.48) & NS (2.41) & 3.10 & 0.99 & 0.91 \\
\hline
\end{tabular}

Table.4 Effect of planting geometry to economy of sugarcane under drip irrigation at Kawardha region

\begin{tabular}{|c|c|c|c|c|c|c|c|}
\hline Treatments & $\begin{array}{l}\text { Gross } \\
\text { Return } \\
\text { (Rs/ha) }\end{array}$ & $\begin{array}{l}\text { Cost of } \\
\text { cultivation } \\
\text { (Rs/ha) }\end{array}$ & $\begin{array}{l}\text { Net return } \\
\text { (Rs/ha) }\end{array}$ & $\begin{array}{l}\text { B:C } \\
\text { ratio }\end{array}$ & $\begin{array}{l}\text { Gross Income } \\
\text { from intercrop } \\
\text { (Rs/ha) }\end{array}$ & $\begin{array}{l}\text { Net } \\
\text { income of } \\
\text { intercrop } \\
\text { (Rs/ha) }\end{array}$ & $\begin{array}{l}\text { Total } \\
\text { income } \\
\text { (Rs/ha) }\end{array}$ \\
\hline$T 1-120 \mathrm{~cm} * 60 \mathrm{~cm}$ & 482000.00 & 84150 & 396450.00 & 4.73 & 88888.89 & 73889 & 470339 \\
\hline$T 2-120 \mathrm{~cm} * 90 \mathrm{~cm}$ & 421000.00 & 83200 & 336800.00 & 4.06 & 85555.56 & 70556 & 407356 \\
\hline$T 3-120 \mathrm{~cm} * 120 \mathrm{~cm}$ & 389000.00 & 79670 & 310330.00 & 3.88 & 87777.78 & 72778 & 383108 \\
\hline T4- $150 \mathrm{~cm} * 60 \mathrm{~cm}$ & 457533.33 & 80980 & 377223.33 & 4.65 & 100000 & 84000 & 461223 \\
\hline T5- $150 \mathrm{~cm} * 90 \mathrm{~cm}$ & 371000.00 & 78600 & 293400.00 & 3.72 & 102222.2 & 86222 & 379622 \\
\hline$T 6-150 \mathrm{~cm} * 120 \mathrm{~cm}$ & 353500.00 & 76866 & 276634.00 & 3.60 & 104444.4 & 88444 & 365078 \\
\hline T7- FP with 2 eye bud & 337400.00 & 74500 & 263900.00 & 3.53 & 70555.56 & 56556 & 320456 \\
\hline T8- FP with 3 eye bud & 328900.00 & 70800 & 258900.00 & 3.65 & 69777.78 & 55778 & 314678 \\
\hline
\end{tabular}


Fig.1 Comparative study of planting geometry to sugarcane yield attributes under drip irrigation

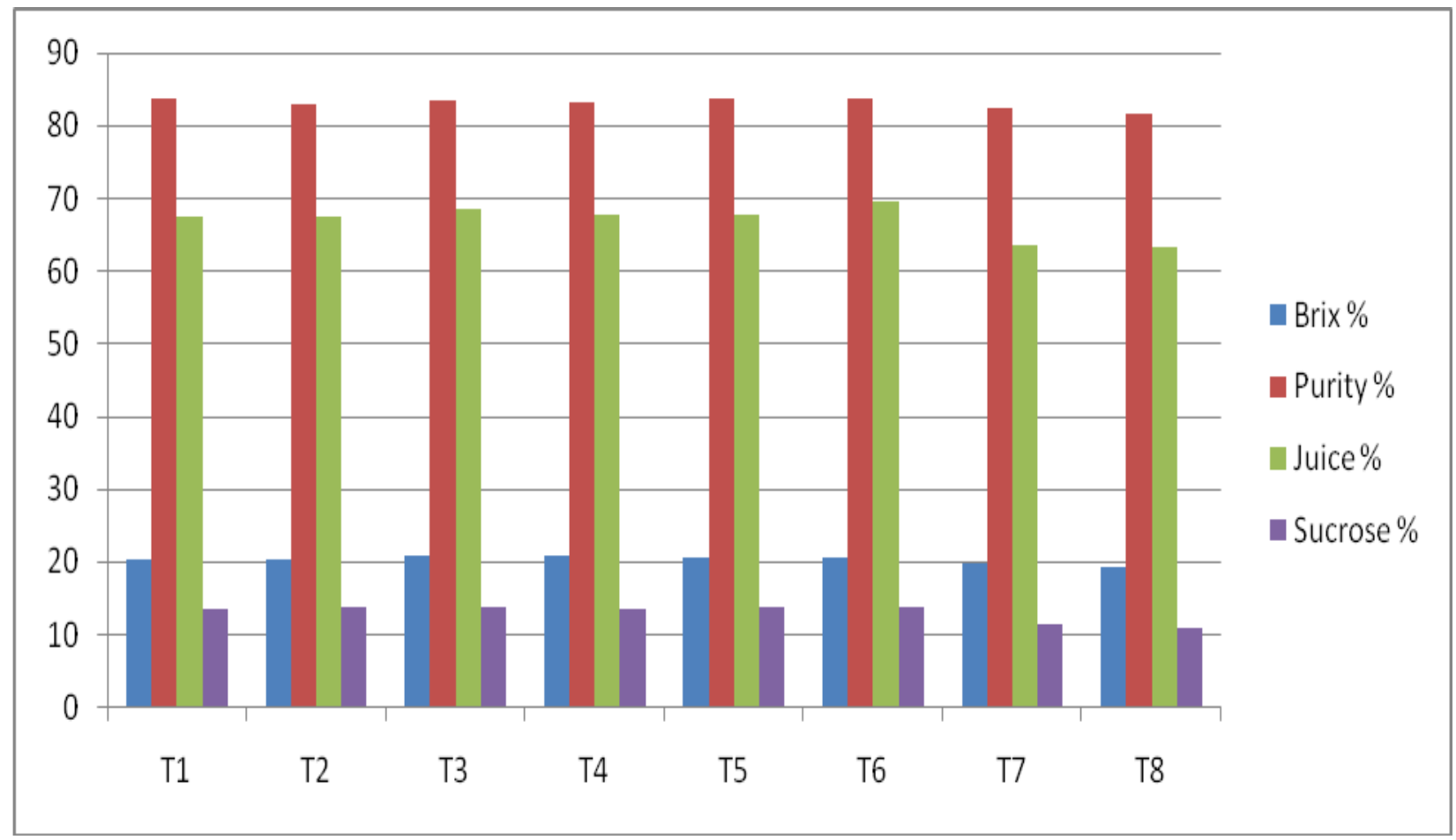

Fig.2 Comparative study of planting geometry to chemical attributes of sugarcane under drip irrigation

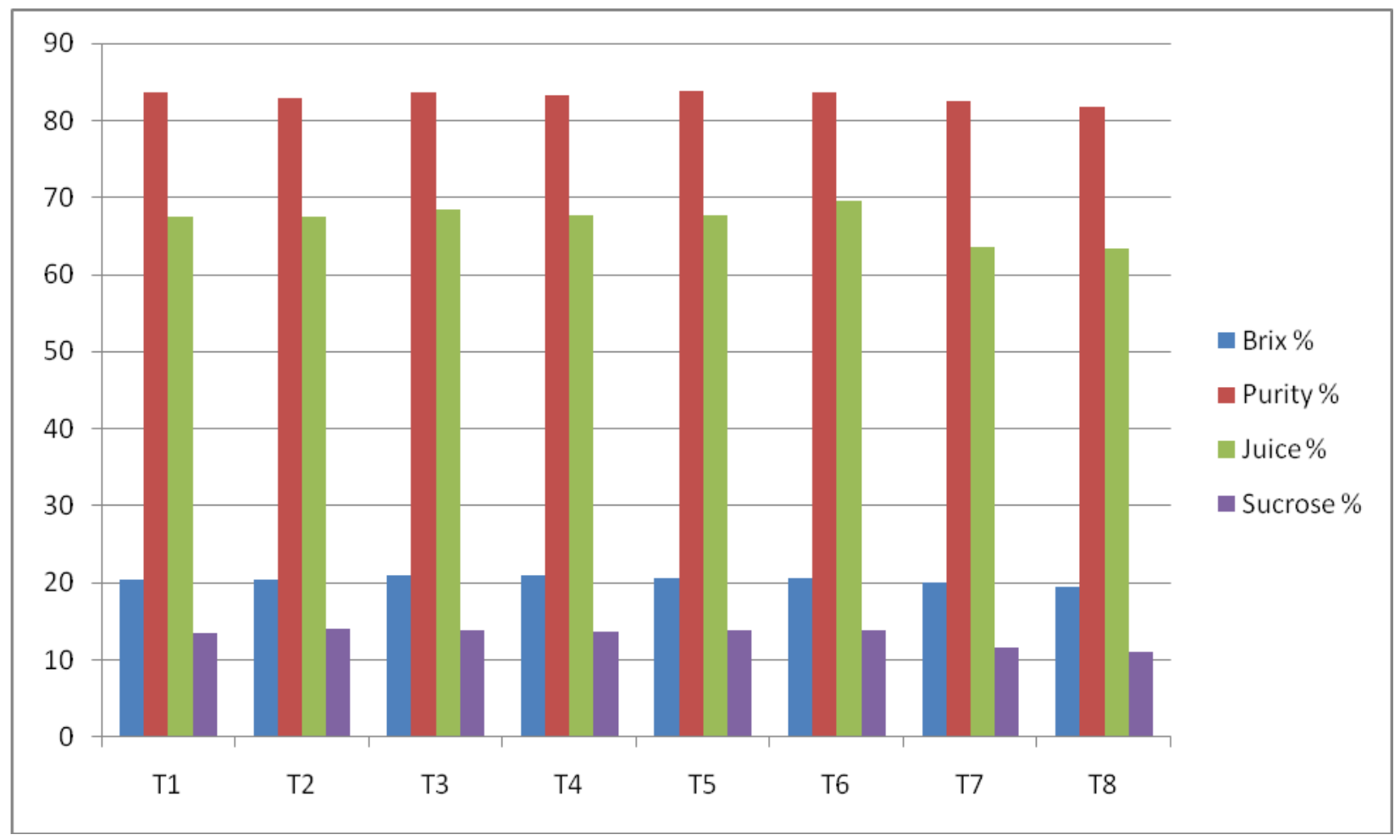


Table.5 Details of the field experiment

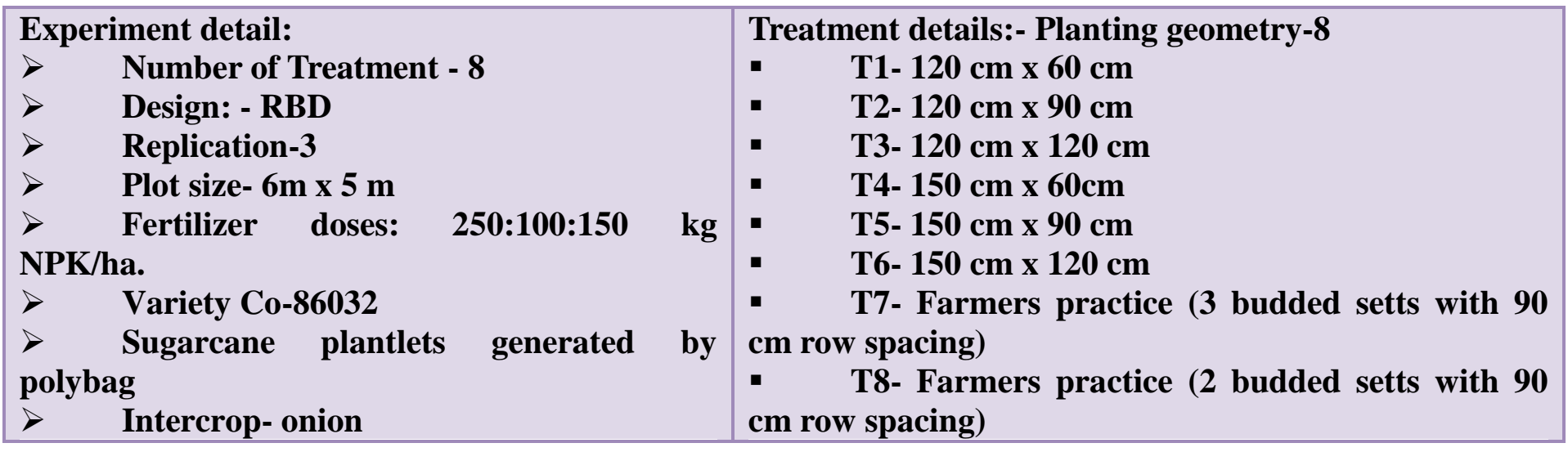

Our study demonstrated that the various quality parameters of sugarcane i.e. brix (\%), purity (\%) Juice (\%), Sucrose (\%) and Recovery $(\%)$ were not affected by different row spacings. Since the rate of fertilizers applied was equal in all the spacings, the quality of sugarcane did not differ significantly. Although all tretment of spacing gave better result than farmer's practices (Table 3). The results are in conformity with the findings of Sarala et al., (2012) and Chakrawal and Kumar (2014).

In case of economy, Net income and B: C ratio has also found higher under spacing 120 $\mathrm{cm} \times 60 \mathrm{~cm}$ compared to Farmer practices and other spacing treatments (Table 4).

\section{References}

Anonymous, 2016, India Sugar Annual 2016. GAIN (Global Agricultural Information Network) Report, USDA Foreign Agricultural Service, p. 2.

Chakrawal, D. and Kumar, N. (2014) Physioagronomic analysis of sugarcane (Saccharum spp. hybrid complex) varieties under different planting geometry. Indian J. Sugarcane Technol., 29(02), 67-71.

Hossain, G. M. A., Bokhtiar, S. M., Paul, S. K. and Anam, M. R. (2003) Intercropping of sugarcane with onion and potato followed by sesame in paired row system. Pakistan J. Agron., 2(2), 85-91.

Patel, D., Raj, V. C., Tandel, B., Patel, B., Patil, P., Patel, A. M. and Patel D. U. (2014b) Sugarcane yield and nutrient uptake under plant geometry and variety in relation to mechanization. The Bioscan, 9(4), 14451448.

Rajula shanthy, T. and Muthusamy, G. R. (2012) Wider row spacing in sugarcane: A socio-economic performance analysis. Sugar Tech, 14 (2), 126-133.

Saini, L. K., Singh, M. and Kapur, M. L. (2003) Relative profitability of intercropping vegetable crops in autumn planted sugarcane. Sugar Tech, 5 (1\&2), 95 - 97.

Sarala, N. V., Subba Rao, M., Hemanth Kumar, M. and Nagamadhuri, K. V. (2014) Response of sugarcane to plant geometry and irrigation methods in southern agroclimatic zone of Andhra Pradesh. J. Sugarcane Res., 4 (1), 86-90.

Singels, A. and Smit, M. A. (2002) The effect of row spacing on an irrigated plant crop of sugarcane variety NCO376. Proc. $76^{\text {th }}$ South African Sugarcane Techno. Ass., South Africa. pp. 94-105.

Varghese, K., Massey, N., Sahotra, R. and Ghosh, G. (2006) Economic evaluation of different companion crops in autumn planted sugarcane (Saccharum officinarum). Agric. Sci. Digest, 26 (1), 77-78. 


\section{How to cite this article:}

Chandrakar, C.K., N. Prabha, O.N. Verma and Pandey, K.K. 2019. Standardization of Planting Geometry of Sugarcane with Suitable Intercropping under Drip Irrigation in Chhattisgarh Plains. Int.J.Curr.Microbiol.App.Sci. 8(07): 2878-2884.

doi: https://doi.org/10.20546/ijcmas.2019.807.358 